\title{
„Tyle wiemy o sobie/ile nas sprawdzono" Recepcja Wisławy Szymborskiej w mediach
}

\author{
„Tyle wiemy o sobie/ile nas sprawdzono" \\ The reception of Wisława Szymborska in the media
}

\begin{abstract}
Summary: The author presents the reception of Wisława Szymborska's work. She shows how the Nobel Prize received by the writer in 1996 caused a sudden increase in interest in her work. This interest has been shown from two perspectives: one is a fascination with poetry and an attempt to put the Nobel Prize winner on a monument, against which the poet herself strongly protested, and the other is the perspective of an open reluctance, not to say hate, resulting from indicating Szymborska's youthful fascination with the ideals of socialism. The article shows how the Internet has become a platform that has helped to promote, above all, the knowledge about the author of the poems and, to a lesser extent, reflection on her work.
\end{abstract}

Key words: Wisława Szymborska, poetry, interpretation, Internet

Tu leży staroświecka jak przecinek

autorka paru wierszy. Wieczny odpoczynek

raczyła dać jej ziemia, pomimo że trup

nie należat do żadnej z literackich grup.

Ale też nic lepszego nie ma na mogile

oprócz tej rymowanki, topianu i sowy.

Przechodniu, wyjmij z teczki mózg elektronowy

i nad losem Szymborskiej podumaj przez chwile ${ }^{1}$.

${ }^{1}$ W. Szymborska: Nagrobek. W: Eadem: Sól. Warszawa 1962, s. 38. 
W wierszu Nagrobek z lat sześćdziesiątych minionego stulecia Wisława Szymborska precyzyjnie usytuowała się po tej stronie rzeczywistości, która daleka jest od współczesnej kultury instant, dokonując przy tym nadzwyczaj trafnej antycypacji dotyczącej postępującej technologizacji społeczeństwa. Poetka, posługując się metaforą przecinka, wykorzystuje go jako ekwiwalent wspomnianej staroświeckości, która stoi w opozycji do postępu, pośpiechu czy ekonomizacji języka. Pomimo uporu i prób odgradzania się od świata technologii łopianem czy sową nie pozostaje nic innego jak akceptacja faktu, że od technologii nie sposób uciec, być może jedynie w refleksję. I tak ostatecznie świat żegnał poetkę w świetle kamer.

Autorka słynnego Kota w pustym mieszkaniu nadal wzbudza kontrowersje, choć odeszła na początku 2012 roku. Na rynku wydawniczym stale obecne są tytuły tomików poetyckich Noblistki, nie słabnie jej popularność, podobnie jak trwa wykorzystywanie wizerunku Szymborskiej, który w czasach kultury obrazkowej zdaje się funkcjonować samoistnie, co zapewne zdziwiłoby „staroświecką jak przecinek / autorkę kilku wierszy"2. Znajduje to praktyczne odzwierciedlenie w słowach Elżbiety Winieckiej, która badając literackość sieci, zauważyła, ,że w Internecie nie da się być po prostu czytelnikiem, obserwatorem, Barthes'owskim łowcą mitów alienującym się od wspólnotowego życia. Korzystanie z Internetu wymusza na nas uczestnictwo"3.

Wisława Szymborska zmarła 1 lutego 2012 roku. Obrzędy pogrzebowe poetki z udziałem najwyższych urzędników państwowych odbyły się w Krakowie, a świecką uroczystość poprowadzoną przez Andrzeja Seweryna transmitowano $\mathrm{w}$ telewizji publicznej. $\mathrm{W}$ południe $\mathrm{z}$ wieży mariackiej popłynęły dźwięki muzyki skomponowanej do wiersza Nic dwa razy. Z perspektywy widza ostatnie pożegnanie poetki miało charakter niezwykle uroczysty, choć trudno nie przypomnieć sobie konwencji ironicznego utworu Noblistki zatytułowanego Pogrzeb, który Małgorzata Antoszewska-Tuora określiła mianem „socjolingwistycznego arcydzieła"4. Zarejestrowane fragmenty tego wydarzenia można nadal obejrzeć w serwisie YouTube. To ogromne poruszenie medialne Piotr Bratkowski w artykule Szymborska. Obłaskawiona śmierć skomentował następującymi słowami:

[...] zapewne czułaby się zawstydzona i zażenowana, że śmierć w końcu wepchnęła ją w niechcianą rolę narodowej celebrytki, że stała się wiadomością dnia. Zarazem jednak - jako uważna obserwatorka współczesnych

2 Ibidem.

${ }^{3}$ E. Winiecka: Literackość sieci, literackość w sieci. Perspektywy badań. „Forum Poetyki” 2016, wiosna/lato, s. 30.

${ }^{4}$ M. Antoszewska-Tuora: Niektórzy lubia Szymborska. Mały przewodnik po twórczości. Warszawa 1996, s. 7. 
przemian i zwłaszcza osobliwości obyczajowych - z pewną fascynacją i rozbawieniem patrzyłaby na współczesny rytuał medialnej żałoby. [...] $\mathrm{Na}$ media wyrywające sobie — choćby odległych — znajomych poetki, gotowych wspomnieć przynajmniej kilka zjedzonych w jej towarzystwie obiadów. Na polityków i inne persony publiczne, na co dzień trzymające się jak najdalej od poezji, teraz jednak odczuwające zbiorową konieczność wypowiedzenia na temat zmarłej Noblistki kilku komunałów $[\ldots]^{5}$.

Wirtualna rzeczywistość stale pogłębiająca ekspansję sfer codziennego funkcjonowania może być wytłumaczeniem, a zarazem przykładem rosnącej popularności tej części sieci, którą można nazwać „uduchowioną”, będącą zarazem znakiem pamięci. Można przytoczyć w tym miejscu rozwijające się strony wirtualnych cmentarzy, o których Ewelina Twardoch pisała, że stają się symbolicznym miejscem pamięci ważnym dla zbiorowości, choć istnieją w siecíb. Wiek XXI można by zatem określić mianem neosemantyczności, w którym Horacjańskie non omnis moriar nabiera coraz to nowych znaczeń, samo zaś wznoszenie wiecznych pomników odbywa się coraz częściej w rzeczywistości wirtualnej (paradoksalnie jednocześnie efemerycznej i trwałej).

Największy boom zainteresowania twórczością i osobą Szymborskiej na rynku wydawniczym nastąpił niewątpliwie po roku 1996, kiedy została laureatką Nagrody Nobla. Kolejną cezurą, która pamięć o poetce odświeżyła, była jej śmierć. Mimo upływu kilku lat popyt na „,szymborskość” nie słabnie. „Oficjalny" telewizyjny wizerunek Szymborskiej jest raczej pozytywny, ciekawe spektrum rozbieżności stanowi Internet, w którym od kilku lat znacząco wzrosła liczba negatywnych komentarzy dotyczących autorki. Opracowania badaczy literatury dotyczące jej poezji stawiają poetkę na piedestale polskich twórców, czego potwierdzeniem mogą być choćby słowa Jana Gondowicza, który przed laty w Oswajaniu poezja pisał: „Poezja Szymborskiej zawiera dokładnie to, czego tradycyjnie brak liryce polskiej. Dystansu w sprawach wielkich, konkretu w sprawach małych, widzenia spraw nowych i myślenia przy sprawach wszelkich"7. Decyzję o wyróżnieniu Szymborskiej Nagrodą Nobla argumentowano przede wszystkim wrażliwym spojrzeniem na człowieka i osobliwym językiem poetyckim: ,„...] za poezję, która z ironiczną precyzją pozwala historycznemu i biologicznemu kontekstowi ukazać się we fragmentach ludzkiej rzeczywistości"». Miłosz pytany o reakcję na tę wiadomość odpowiedział, że

${ }^{5}$ P. Bratkowski: Szymborska. Obłaskawiona śmierć. https://www.newsweek.pl/pogrzebwislawy-szymborskiej-oblaskawiona-smierc-szymborskiej/jxkv5f3 [data dostępu: 15.02.2019].

${ }^{6}$ Zob. E. Twardoch: „Usieciowione” miejsca pamięci, czyli jak symbole przeszłości staja się przestrzenia aktywności użytkowników sieci. http://www.ejournals.eu/sj/index.php/PK/article/ view/4443/4418 [data dostępu: 15.02.2019].

7 J. Gondowicz: Oswajanie poezja. „Kultura” 1973, nr 15, s. 3.

${ }^{8}$ www.noblisci.pl/1996-wislawa-szymborska [data dostępu: 15.02.2019]. 
spodziewał się jej i jest to kolejny dowód na to, że „Polska poezja jest uważana przez wielu ludzi za najlepszą w Europie kontynentalnej”"9.

W przestrzeni popularnej (Internet) próżno szukać analiz procesu literackiej ewolucji twórczości Wisławy Szymborskiej, które nie byłyby szkolnym omówieniem wierszy znajdujących się w edukacyjnej podstawie programowej. Znaleźć można natomiast wiele treści związanych z medialnym wizerunkiem autorki, który wykreowała nie sama zainteresowana (lub raczej niezainteresowana), lecz internauci. Nobel dla Szymborskiej wzbudził także kontrowersje. Jedną z negatywnych reakcji na werdykt szwedzkiego jury była praca Ewy i Stanisława Krajskich Dwie twarze Wisławy Szymborskiej, których swoistego rodzaju misją stało się ,udowodnienie”, że Nobel poetce się nie należy, a wszystko za sprawą socrealistycznej przeszłości. W zakończeniu autorzy powołują się na dobro młodzieży, która powinna być wychowywana w duchu prawdy, a jak można to czynić, skoro uznana za jedną z najwybitniejszych poetek „uwikłana jest” w przeszłość godną — według autorów — najwyższego potępienia. Praca autorów Dwóch twarzy... sprawia wrażenie napisanej w ten sposób, jak gdyby obrali sobie za cel zniesławienie Szymborskiej, powołując się przy tym na dziwnego rodzaju „klauzulę sumienia”, która w tej formie przybiera kształt fanatyzmu. Pozycja ta nie zawiera w zasadzie rzeczowego omówienia twórczości poetki, jest wybiórcza, a przy tym publicystycznie subiektywna:

Co powiemy naszemu dziecku [...], gdy weźmie udział w kreowaniu jakiejś jutrzejszej Nowej Huty, gdy będzie dzieciom czy wnukom naszych bliskich wciskać kit jakiejś nowej totalitarnej ideologii i propagandy? Czego byśmy mu nie powiedzieli, ono może nam zamknąć usta stwierdzeniem: „I tak za kilkadziesiąt lat dostanę Nobla, i wszyscy zapomną, i będę chodzić w glorii, i chwale, i nurzać się w bogactwie [... $]^{\prime 10}$.

Na uwagę zasługuje również fakt, że książka ukazała się nakładem wydawnictwa katolickiego, które najwyraźniej także nie było Szymborskiej przychylne. Ale każdy medal ma dwie strony (o czym Krajscy najwyraźniej zapomnieli, tytułując swoją pracę „dwiema twarzami” Szymborskiej, a pisząc ciągle o jednej), dlatego warto wspomnieć o wypowiedzi ks. Jana Twardowskiego, który książkę Krajskich „określił mianem rzeczy paskudnej i zjadliwej”" w latach siedemdziesiątych minionego stulecia Artur Sandauer nie miał wątpliwości co do nowatorstwa tej poezji, akcentował, że cechuje ją przede wszystkim nowoczesność myślenia, a nie stylu:

${ }^{9}$ Obmyślam świat, czyli o poezji Wisławy Szymborskiej. Red. S. Żak. Kielce 1998, s. 11.

${ }^{10}$ E. Krajska, S. Kraj ski: Dwie twarze Wistawy Szymborskiej. Warszawa 1996, s. 126.

${ }^{11}$ Wywiad z ks. J. Twardowskim przeprowadziła A. Bernat. Zob. „Gazeta Wyborcza” z 24-26.12.1996. 
Wydaje się, że między dwoma skrzydłami naszej literatury poezja ta potrafiła znaleźć słuszną miarę. Nie jest ani tradycjonalnie moralistyczna, ani awangardowo-artystowska: jest po prostu doskonała ${ }^{12}$.

Szymborska „przed Noblem” nie była szczególnie popularną autorką. Wspomina o tym choćby Jan Tomkowski w swojej pracy Dwadzieścia lat z literatura 1977-1996:

Rozkładali bezradnie ręce polscy goście na odbywających się międzynarodowych targach księgarskich we Frankfurcie. Egzemplarz najnowszego zbiorku Szymborskiej podobno był, ale ktoś go ukradł. [...] Ani jednego tomiku. Ani jednego wyboru wierszy, ani jednej monografii. [...] Kilka miesięcy później poezje Szymborskiej (również w pirackich edycjach) sprzedawano nawet na łóżkach polowych, zastępujących księgarską ladę. Laureatkę zobaczyliśmy wreszcie w telewizji. Poetką zainteresować się musiały mass media ${ }^{13}$.

Niejednoznaczny odbiór poetki z biegiem lat nie słabnie. Dużo krytyki skierowanej w jej stronę znaleźć można na profilu Szymborskiej na największym portalu filmowym w Polsce. Negatywne komentarze dotyczą najczęściej przeszłości politycznej autorki. Z kolei na portalu Facebook widnieje wiele stron poświęconych poetce (w tym oficjalna). Za przykład posłużyć może fan page: „Nie być bokserem, być poetą”, którego zdjęciem profilowym jest uśmiechnięta Szymborska w rękawicach bokserskich. Specyficzna natura wirtualnego świata operuje humorem, ironią, a nawet pastiszem czy groteską, co może tłumaczyć niektóre treści rodzące się w Internecie. I tak, odpowiedzią tej sfery medialnej na kontrowersyjną kampanię z 2015 roku „Nie zdążyłam zostać mamą” okazały się treści, których bohaterką stała się między innymi Wisława Szymborska. W sieci pojawiało się zdjęcie poetki z podpisem: „Zdążyłam wydać 13 tomów wierszy przetłumaczonych na 42 języki, zdążyłam dostać Nobla, zdążyłam zostawić w spadku kasę na najwyższą nagrodę literacką w Polsce, ale... nie zdążyłam zostać mamą"14.

Istotne staje się zatem pytanie: czy kierunek, w którym zmierza wykorzystywanie wizerunków osób publicznych, nie jest przekraczaniem granic dobrego smaku? Szymborska jest cały czas obecna w świadomości młodej części społeczeństwa, gdyż to właśnie ono staje się przede wszystkim autorami popularnych dziś memów. Być może wiąże się to z powszechnie znanym umiło-

12 A. Sandauer: Pogodzona z historia. W: Idem: Poeci czterech pokoleń. Kraków 1977, s. 312 .

13 J. Tomkowski: Dwadzieścia lat z literatura 1977-1996. Warszawa 1998, s. 148

${ }^{14}$ www.facebook.com/niebycbokserembycpoeta [data dostępu: 15.02.2019]. 
waniem poetki do tworzenia poezji niekonwencjonalnej, niskiej, o zabarwieniu żartobliwym. „Lepieje hotelowe”, limeryki tworzone pod wpływem olśnienia nazwą mijanej właśnie przez nią miejscowości, przesycone czarnym humorem nekrologi były, według niej, pełnoprawną częścią jej dorobku artystycznego. Szymborska nie bała się uciekać do kiczu, który dziś można by określić mianem guilty pleasure. Wyklejanki, kolaże czy legendarne loteryjki, które organizowała w swoim mieszkaniu, są częścią legendy tej niejednoznacznej poetki. Zdaje się, że „nobliwa” Noblistka - jak chcieliby postrzegać ją jedni (wtłaczając na literacki parnas) — nie tworzy dysonansu z pełną autoironii i nietuzinkowego humoru autorką.

Wisława Szymborska wraz z Włodzimierzem Maciągiem przez lata prowadziła Pocztę Literacką na łamach „Życia Literackiego”, w której wspólnie odpowiadali na listy czytelników. Zabawne odpowiedzi redakcji zostały po latach opublikowane. W rozmowie z Teresą Walas, która poprzedza wydanie barwnych odpowiedzi Poczty literackiej, czyli jak zostać (lub nie zostać) pisarzem, Szymborska stwierdziła, że była to przede wszystkim zabawa, która miała promować czytelnictwo i zachęcać do autorefleksji nad tekstami. Wielu chciałoby Szymborską zaszufladkować, ale biorąc pod uwagę jej chęć łączenia przeciwieństw, zarówno ta twórczość, jak i życiorys wymykają się ostatecznie sztywnym ramom konformistycznych zachcianek porządkowania świata w taki sposób, w jaki chcielibyśmy go oglądać. Literacki Nobel i tytuł „Machinera Roku” (czasopismo popkulturowe „Machina”) w 1996? Dlaczego nie. Tytuł człowieka „Wprost” roku '96 wraz z wizerunkiem poetki i nagłówkiem „Dyktatura podwyżek. Jak przetrwać mrozy”, proszę bardzo. Michał Rusinek wspominał też o osobliwej korespondencji, którą Szymborska otrzymywała od czytelników (fanów?), w której pojawiały się takie zwroty grzecznościowe, jak: Królowo Poezji!, Sapho Nadwiślańska, Czcigodna Matko Poezji!, Czcigodna Laureatko, Urocza Pani Wiesiu!, Szymborska!, Prof. dr Wiestawo! Szymborska natomiast często podkreślała swoją sympatię do Andrzeja Gołoty. Po śmierci poetki bokser pożegnał ją słowami:

\section{Braknie mi Ciebie w moim narożniku}

mimo że nigdy nie stapałaś po ringu.

Pozostana wiersze.

„Dziękuje” to za mało... ${ }^{15}$.

Choć poezja i boks to raczej niecodzienne połączenie, Szymborskiej po raz kolejny udało się udowodnić, że nie ma takich przeciwieństw, których nie dałoby się zjednoczyć. Poezja, przekraczając granice, potrafi dowieść, że bariery

15 http://www.polskieradio.pl/5/3/Artykul/533743, Golota-do-Szymborskiej-braknie-mi-Ciebie-w-moim-narozniku [data dostępu: 15.02.2019]. 
i podziały tak naprawdę nie istnieją, to ludzie tworzą je sami. „Boks pojawia się w twórczości Szymborskiej, a także w rozmowach z nią, na zasadzie przeciwwagi dla poezji. [...] Ją to przeciwieństwo fascynuje"16 — napisał Michał Rusinek w Nic zwyczajnego. O Wistawie Szymborskiej.

Współczesny twórca jawi się jako „efemeryczny autor do kochania"17. Taką tezę wysnuł Dominik Antonik, który podaje jako oczywistość, że taki właśnie proces zaszed $ł$ w przypadku legendy Szymborskiej. Jednym z najbardziej charakterystycznych znaków rozpoznawczych poetki będzie papieros, z którym często pojawiała się na zdjęciach. Jest to swoisty znak marki:

Takie elementy twórczości Szymborskiej, jak konkretne wizerunki, upodobania, gesty czy zapadające w pamięć cytaty, zaczynają krążyć w przestrzeni publicznej i wyobraźni społecznej jako intensywności i afekty pobudzania $^{18}$.

Autor zwraca uwagę na transmedialną przestrzeń tej twórczości, w której przedmioty, rekwizyty tworzą spójny literacki świat. Ekonomia afektywna literatury — jak wyjaśnia Antonik — „projektuje w świadomości społecznej nacechowany emocjonalnie obraz autora, $\mathrm{z}$ którym można wchodzić w uczuciowe relacje, a w tekstach, mediach i przestrzeni publicznej instaluje punkty dostępu do marki" ${ }^{19}$. Afektowość rozumiana jako zdolność do oddziaływania na odbiorcę nie tylko na tle doświadczenia literackiego sprawia, że dokonania autora są czymś więcej niż zbiorem utworów o konkretnych walorach artystycznych. Stają się pewnego rodzaju przekaźnikiem, literacką grą, polem, na którym czytelnik, już nie tylko jako odbiorca, ale uczestnik i współtwórca, może identyfikować się z twórczością konkretnego pisarza. Autorka Końca i początku w przedmowie do Nowych lektur obowiazkowych napisała:

Wydawnictwo nalegało, żebym w tym kolejnym tomiku Lektur nadobowiązkowych napisała kilka zdań „od Autorki — do Czytelników”. Ale od autorki jest tu przecież każdy felieton, łącznie z przecinkami i kropkami. I do kogo zwrócony, jak nie do Czytelników? Czyli do Was, moi cierpliwi i nie zanadto grymaśni, Marysiu, Tadeuszu, Bonifacy, Piotrze [...] i Ty, droga mi bardzo Reszto Kalendarza ${ }^{20}$.

${ }^{16}$ M. Rusinek: Nic zwyczajnego. O Wistawie Szymborskiej. Kraków 2016, s. 96.

${ }_{17}$ D. Antonik: Literatura i ekonomia afektywna. Autor do kochania. W: Pamięć i afekty. Red. R. Nycz, Z. Budrewicz. Warszawa 2014, s. 128.

18 Ibidem, s. 129.

19 Ibidem, s. 141.

${ }^{20}$ W. Szymborska: Wstep. W: Eadem: Nowe lektury nadobowiazkowe 1997-2002. Kraków 2002. 
Sugestia (nazwijmy to w ten sposób) wydawnictwa, skierowana do autorki to przykład działania współczesnych mechanizmów, które przez różnego rodzaju próby personalizowania aktu komunikacji między adresatem i odbiorcą mają sprawiać wrażenie osobistego. Przestrzeń internetowa umożliwia obecnie w pewnej mierze prywatne kontakty z autorem. Wystarczy wejść na stronę poświęconą Wisławie Szymborskiej, aby posłuchać czytanych przez nią wierszy. Wcześniej tego rodzaju doświadczenie było możliwe jedynie dla wybranych osób, którym udało się uczestniczyć w spotkaniach autorskich. Moralitet leśny, jeden z zarejestrowanych wierszy, poprzedzony jest fragmentem spontanicznej rozmowy między poetką a Michałem Rusinkiem: „Może proszę napić się kawy. Kawa dobrze robi”, „Co pan mówi. Mnie już nic dobrze nie zrobi!”21. Ten specyficzny rodzaj łączności z autorem wywołuje złudne wrażenie bezpośredniego kontaktu. Fragmenty nieoficjalnych wypowiedzi osoby publicznej rozmywają granice, które jeszcze kilkanaście lat temu były nie do pokonania. Wirtualna rzeczywistość coraz częściej przekłada się na realne życie. Ludzie „zaprzyjaźniają się" ze swoimi idolami, do których życia mają dostęp po kilku kliknięciach w Internecie. W powszechnym obiegu od lat krąży także jeden $\mathrm{z}$ najbardziej znanych mitów internetowych, według którego Noblistka nie zdała matury ze swoich wierszy. Nieporozumienie to wyjaśnił Michał Rusinek; źródłem stał się artykuł, który ukazał się w „Dzienniku” w 2009 roku. Znalazł się w nim felieton autorstwa Jerzego Sosnowskiego Sztuka jako schody ruchome, w którym autor opisał trudności, jakie sprawiło mu rozwiązanie zadań maturalnych zgodnie z kluczem odpowiedzi do własnego tekstu. Ponieważ wiersze Szymborskiej często w arkuszach maturalnych występują, powstała legenda, która połączyła oba fakty i stworzyła historię, tak naprawdę nieprawdziwą.

W utworach poetki niezwykły potencjał szybko dostrzegli muzycy, adaptując je jako teksty piosenek. W roku 1965 w Sopocie Nic dwa razy wykonała Łucja Prus. Ten sam wiersz zyskał dużą sławę na początku lat dziewięćdziesiątych za sprawą rockowej aranżacji zespołu Maanam. Kolejnym przykładem jest muzyka skomponowana przez Zbigniewa Preisnera do wiersza Miłość od pierwszego wejrzenia, który wyśpiewał Zbigniew Zamachowski w filmie Trzy kolory: Czerwony (1994) w reżyserii Krzysztofa Kieślowskiego. Przejmujący wiersz Nienawiść w jazzowym stylu wykonała Hanna Banaszak, a Magda Umer doskonale oddała swoim wokalem klimat wiersza Buffo. Kolejny przykład to Allegro ma non troppo, do którego muzykę skomponował (zarazem wykonując utwór) Stanisław Soyka. Miłosną lirykę Upamiętnienia do swojego repertuaru włączyli Skaldowie, Atlantydę zaś w muzycznej oprawie zamieścił na płycie To tu, to tam Grzegorz Turnau. W 2013 roku ukazał się album studyjny wybitnego polskiego kompozytora i jazzmana Tomasza Stańki zatytułowany Wisława poświęcony w całości Noblistce. Stańko wypowiedział się o poetce tymi słowami:

${ }^{21} \mathrm{http}: / /$ www.szymborska.org.pl/galeria-audio.html [data dostępu: 15.02.2019]. 
Kontakt z poezją Wisławy Szymborskiej poruszył mnie do głębi i niezwykle zainspirował. Spotkanie z Poetką na estradzie oraz możliwość improwizowania do wierszy czytanych przez Nią dały mi jeszcze większy impuls twórczy. Powstała muzyka, którą z najgłębszym uznaniem chciałbym zadedykować pamięci Wisławy Szymborskiej22.

Jednym z najbardziej interesujących hołdów złożonych Wisławie Szymborskiej po jej śmierci był projekt autorstwa Sztucznych Fiołków. To strona prowadzona na portalu Facebook od 2012 roku, której autor wykorzystuje znane dzieła sztuki i dodaje do nich błyskotliwe uwagi dotyczące aktualnych wydarzeń ze świata kultury i polityki. Strona zdobyła ogromną popularność, podobnym uznaniem cieszył się również projekt poświęcony poetce ${ }^{23}$.

W 2013 roku, w dziewięćdziesiątą rocznicę urodzin poetki, wyszukiwarka Google uhonorowała Szymborską w charakterystyczny dla siebie sposób, to znaczy przez opracowanie doodle'a, który odsyłał do biografii poetki ${ }^{24}$.

Proces przejmowania elementów kultury wysokiej do kultury popularnej przebiega między innymi w efekcie włączania elementów sztuki wysokiej do „realnej” rzeczywistości. Koszulki, torby płócienne z fragmentami wierszy poetów lub ich wizerunkami (najczęściej uwspółcześnionymi, w stylu pop-art). Poezja wyszła na ulicę, już nie tylko gusta muzyczne znajdują swe odzwierciedlenie w wyglądzie uczestników kultury. Marketingowcy szybko dostrzegli w tym potencjał, odpowiadając na potrzeby społeczeństwa. Pod koniec 2013 roku Empik we współpracy z Fundacją Wisławy Szymborskiej przygotował limitowaną kolekcję upamiętniającą postać autorki oraz jej twórczość, wykorzystując do tego produkty użytku codziennego (zeszyty, zakładki do książek, podkładki stołowe, magnesy na lodówkę).

W czerwcu 2015 roku ukazał się na rynku wybór wierszy poetki w języku esperanto, nad którego przygotowaniem czuwał Profesor Wojciech Ligęza. Publikacja zawiera 190 utworów. Sama fundacja powstała w kwietniu 2012 roku jako wyraz ostatniej woli Noblistki. Fundacja przyznaje międzynarodową nagrodę poetycką imienia twórczyni, a od roku ubiegłego — również laur w ramach konkursu imienia Adama Włodka. Grudzień tego samego roku przyniósł Szymborskiej uznanie w Stanach Zjednoczonych. Ukazała się wówczas publikacja prezentująca wiersze Szymborskiej, a także fakty z jej życia i kariery

${ }^{22} \mathrm{http}: / /$ www.tomaszstanko.com/pl/nowy-album-tomasz-stanko-new-york-quartet-wislawa -ecm/ [data dostępu: 15.02.2019].

${ }^{23}$ Warto zobaczyć projekt przedstawiający obraz Pietera Brueghla (starszego) z komentarzami odnoszącymi się do śmierci poetki. Zob. https://www.facebook.com/SztuczneFiolki/photos/a.4 83789074973669.115138.483774998308410/486192604733316/?type=1\&theater [data dostępu: 15.02.2019].

${ }^{24}$ Zob. http://www.wprost.pl/ar/406556/Kot-w-pustym-pokoju-na-90-urodziny-WislawySzymborskiej/ [data dostępu: 15.02.2019]. 
literackiej; powstała ona między innymi przy współpracy tłumaczki (współdziałającej zresztą ze Stanisławem Barańczakiem przy przekładzie wierszy Szymborskiej) Clare Cavanagh, Michała Rusinka oraz Krystyny Dąbrowskiej. O prestiżu publikacji świadczy fakt, że jej premiera określona została mianem dużego wydarzenia kulturalnego, rekomendowanego na stronach dotyczących aktualnych nowojorskich wydarzeń ${ }^{25}$. Autorka Końca i początku stała się również przypadkową uczestniczką wyborów parlamentarnych w październiku 2015 roku, kiedy została omyłkowo wzięta za premier Beatę Szydło. Nagranie szybko stało się viralem, a wypowiedź o tym, że byłaby odpowiednią kandydatką na premiera, ponieważ „mogłaby zrobić wiele dla starszych ludzi”, błyskawicznie obiegła sieć ${ }^{26}$. Rok później Szymborska zyskała rozgłos w Chinach i na Tajwanie za sprawą singla Hebe Tien inspirowanego wierszem Pod jedna gwiazdka. Wokalistka wplata weń fragment utworu, recytując go w języku polskim $^{27}$.

Wydany pod koniec 2016 roku zbiór listów Szymborskiej i Kornela Filipowicza, zatytułowany Najlepiej w życiu ma twój kot, potwierdził, że formy epistolarne cieszą się ogromnym zainteresowaniem czytelników. Nie powinien więc dziwić fakt, że 2018 rok przyniósł publikację korespondencji między Szymborską a Miłoszem, którą wymieniali między sobą w latach 1955-1996 (Jacyś złośliwi bogowie zakpili z nas okrutnie). Za życia Szymborskiej nie ukazał się także zbiór poezji Czarna piosenka, który miał być debiutanckim tomem autorki Wołania do Yeti. Ostatecznie ukazał się po jej śmierci, dzięki Adamowi Włodkowi, który ocalił od zapomnienia wiersze z wczesnego okresu literackiej drogi Szymborskiej nigdy nieopublikowane lub rozproszone po różnych czasopismach. Joanna Szczęsna - autorka wstępu do Czarnej piosenki — podkreśla, że tom ten jest niezbędny do wypełnienia luki w postaci opisu doświadczenia wojny, o którym w późniejszych latach Szymborska pisała rzadko.

Nie brakuje także publikacji zagranicznych, dotyczących życia i twórczości polskiej poetki. Jednym z najciekawszych projektów ostatnich lat okazała się powieść obrazkowa włoskiej graficzki Alice Milani, która barwne życie Wisławy Szymborskiej zaprezentowała w formie komiksu, połączonego z lubianą przez samą poetkę techniką kolażu. Książka zawiera fragmenty wierszy, parafrazy jej wypowiedzi oraz bliskie sercu przedmioty i stworzenia ${ }^{28}$. Do obrazkowej biografii włączony został kot, którego Szymborska w rzeczywistości nigdy nie miała. Napisany po śmierci Filipowicza Kot w pustym mieszkaniu stał

${ }^{25} \mathrm{https}$ ://poland.us/strona,55,21819,0,a-celebration-of-wislawa-szymborska-winner-of-the -nobel-prize-in-new-york.html [data dostępu: 15.02.2019].

$26 \mathrm{https}: / /$ dziendobry.tvn.pl/a/szymborska-uratuje-polske [data dostępu: 15.02.2019].

${ }^{27} \mathrm{http}: / /$ culture.pl/pl/artykul/szymborska-ikona-mandopopu [data dostępu: 15.02.2019].

${ }^{28}$ Zob. A. Milani: Wisława Szymborska. Życie w obrazkach. Tłum. J. Wajs. Kraków 2016, s. $42-43$. 
się nośnikiem znaczeń, które skupiają wokół siebie treści i znaczenia związane z Szymborską.

Zagraniczne media obiegła także grafika szwedzkiej ilustratorki, przedstawiająca czternaście kobiet, które w latach 1901—2015 zdobyły Nagrodę Nobla w dziedzinie literatury ${ }^{29}$.

Z kolei rok 2017 przyniósł słuchowisko Aldony Kopkiewicz pt. Kobiety, którymi nie byłam poświęcone poezji Noblistki. Przeprowadzona wśród studentów przez Karola Maliszewskiego ankieta dotycząca odbioru poezji Wisławy Szymborskiej i śladów inspiracji w wierszach i świadomości młodego pokolenia wykazała, że wpływy te są mniejsze niż w przypadku takich poetów, jak Zbigniew Herbert, Czesław Miłosz czy Tadeusz Różewicz. Maliszewski prześledził tropy i nawiązania do poezji Noblistki w twórczości młodych poetów, podając takie przykłady, jak tytuł zbioru poezji Grzegorza Olszańskiego z lat dziewięćdziesiątych Tamagotchi w pustym mieszkaniu czy przytaczając wiersz Darka Foksa: wychodzę z księgarni / [...] i nie kupuję Końca i początku chociaż właściwie / powinienem bo mam Wielka liczbę i Ludzi na moście / i nikt nie wie czy wystarczy Końca i początku ponieważ / wystarczy odkładam książke na pótkę i biorę kilka innych ${ }^{30}$.

W 2018 roku rynek wzbogaciła kolejna znakomita książka Tadeusza Nyczka Wistawa Szymborska i choć wydawałoby się, że o poezji Szymborskiej napisano już wszystko, Nyczek po raz kolejny udowodnił, że to nieprawda. Podobnie jak odbiór poezji zmienia się w zależności od okoliczności, doświadczeń, traum i powszechnych oczekiwań w stosunku do samych tekstów, świat także nie ustaje w cyklu śmierci i odradzania się. Szymborską fascynował świat przyrody, w ciekawy sposób ujął to Miłosz:

Szymborska mówi ,ja”, ale to jest ,ja” ascetyczne, oczyszczone z wszelkiej ochoty do wyznań i właściwie z cech indywidualnych, natomiast sprzęgnięte z innymi ,ja" w jednej i tej samej kondycji ludzkiej. [...] Świadomość, którą bada Szymborska, jest „nasza”, bo dostatecznie dzisiaj powszechna, uzyskana dzięki szkole, lekturom. [...] Lekcje biologii w szkole zdają się $[\ldots]$ fundamentem jej światopoglądu, wiele jej wierszy wywodzi się wprost $\mathrm{z}$ teorii ewolucji ${ }^{31}$.

${ }^{29}$ Zob. https://www.facebook.com/nobelprize/photos/ [data dostępu: 15.02.2019].

${ }^{30}$ K. Maliszew ski: Szymborska w oczach nastęnyych pokoleń. Ślady w wierszach i świadomości. Wystąpienie Karola Maliszewskiego na konferencji naukowej Szymborska 20 lat po Noblu 11-12 października 2016. r. http://www.szymborska.org.pl/dokumenty/1484817786_51805587_ Szymborska_w_oczach_nastepnych_pokolen.pdf [data dostępu: 15.02.2019].

${ }^{31}$ C. Miłosz: Poezja jako świadomość. W: Szymborska. Szkice o wierszach Noblistki piszą: Edward Balcerzan, Matgorzata Baranowska, Stanistaw Barańczak, Grażyna Borkowska, Jerzy Jarzębski, Wojciech Ligęza, Jacek Lukasiewicz, Czesław Miłosz, Leonard Neuger. Warszawa 1996, s. 9-10. 
Szymborska potrafiła pisać o strzykwach (Autotomia), morenach i murenach (Urodziny), nie powinno zatem dziwić, że jeden z jej wierszy zatytułowany $O t$ wornice (tom Tutaj 2009) poświęcony był jednokomórkowym pierwotniakom. Przy okazji odkrycia nowego gatunku otwornicy został on nazwany na cześć poetki „cyrea Szymborska”32. Wspomnienie o Szymborskiej utrwalił spektakl norweskiego teatru w Oslo. Przeniesiono na deski teatru opowieść o życiu Szymborskiej. Wydarzeniu teatralnemu towarzyszy wystawa kolaży poetki, a także premiera dwujęzycznego ilustrowanego albumu, który do księgarń trafił 14 lutego 2019 roku. Punkty zwrotne/Turning Points zawiera sylwetki czołowych twórców kultury, którzy prezentowani są przez pryzmat przełomowych wydarzeń w ich życiu ${ }^{33}$.

To, co wydaje się niezwykłe, to fakt, że Szymborską zdołała mocno zaanektować kultura popularna. W kontekście tej premiery wydawniczej o Szymborskiej kolejny raz będzie mówiło się nie w aspekcie jej wierszy, lecz wizerunku medialnego podsyconego przyznaniem Nagrody Nobla, wydarzenia określonego przez przyjaciół laureatki mianem ,tragedii sztokholmskiej”. I choć od śmierci ,pani od poezji” minęło już kilka lat, legenda jej osoby nie gaśnie, a skoro każdy medal musi mieć dwie strony, to i recepcja Szymborskiej przybiera różne formy: od wyrazów uwielbienia do nienawistnych komentarzy. Ciekawe, co Szymborska myślałaby na ten temat? Być może zbyłaby to machnięciem ręki i parafrazą wersu ze swojego wiersza o tym, że znajdą się tacy, których zacznie to nudzić, ale przecież cykle końca i początku jawią się niczym koncentryczne kręgi na wodzie, w której wszyscy jesteśmy zanurzeni.

\section{Bibliografia}

Antonik D.: Literatura i ekonomia afektywna. Autor do kochania. W: Pamięć i afekty. Red. R. Nycz, Z. Budrewicz. Warszawa 2014.

Antoszewska-Tuora M.: Niektórzy lubia Szymborska. Mały przewodnik po twórczości. Warszawa 1996.

Gondowicz J.: Oswajanie poezja. „Kultura” 1973, nr 15, s. 3.

Krajska E., Krajski S.: Dwie twarze Wistawy Szymborskiej. Warszawa 1996.

Milani A.: Wistawa Szymborska. Życie w obrazkach. Tłum. J. Wajs. Kraków 2016.

Miłosz C.: Poezja jako świadomość. W: Szymborska. Szkice o wierszach Noblistki pisza: Edward Balcerzan, Małgorzata Baranowska, Stanisław Barańczak, Grażyna Borkowska, Jerzy Jarzębski, Wojciech Ligęza, Jacek Łukasiewicz, Czesław Miłosz, Leonard Neuger. Warszawa 1996.

32 http://wyborcza.pl/7,75399,23367974,cyrea-szymborska-nowy-gatunek-nazwany-na -czesc-polskiej-poetki.html [data dostępu: 15.02.2019].

$33 \mathrm{https}: / /$ www.vogue.pl/a/wislawa-szymborska-przyjmuje-nagrode-nobla [data dostępu: 15.02.2019]. 
Obmyślam świat, czyli o poezji Wisławy Szymborskiej. Red. S. Żak. Kielce 1998.

Rusinek M.: Nic zwyczajnego. O Wisławie Szymborskiej. Kraków 2016.

Sandauer A.: Pogodzona z historia. W: Idem: Poeci czterech pokoleń. Kraków 1977.

Szymborska W.: Nagrobek. W: Eadem: Sól. Warszawa 1962.

Szymborska W.: Wstep. W: Eadem: Nowe lektury nadobowiazkowe 1997-2002. Kraków 2002.

Tomkowski J.: Dwadzieścia lat z literatura 1977-1996. Warszawa 1998.

Winiecka E.: Literackość sieci, literackość w sieci. Perspektywy badań. „Forum Poetyki” 2016, wiosna/lato.

\section{Źródła internetowe}

Bratkowski P.: Szymborska. Obłaskawiona śmierć. https://www.newsweek.pl/pogrzeb-wislawy -szymborskiej-oblaskawiona-smierc-szymborskiej/jxkv5f3 [data dostępu: 15.02.2019].

http://culture.pl/pl/artykul/szymborska-ikona-mandopopu [data dostępu: 15.02.2019].

http://www.polskieradio.pl/5/3/Artykul/533743, Golota-do-Szymborskiej-braknie-mi-Ciebie-w -moim-narozniku [data dostępu: 15.02.2019].

http://www.szymborska.org.pl/galeria-audio.html [data dostępu: 15.02.2019].

http://www.tomaszstanko.com/pl/nowy-album-tomasz-stanko-new-york-quartet-wislawa-ecm/

[data dostępu: 15.02.2019].

http://www.wprost.pl/ar/406556/Kot-w-pustym-pokoju-na-90-urodziny-Wislawy-Szymborskiej/

[data dostępu: 15.02.2019].

http://wyborcza.pl/7,75399,23367974,cyrea-szymborska-nowy-gatunek-nazwany-na-czesc

-polskiej-poetki.html [data dostępu: 15.02.2019].

https://dziendobry.tvn.pl/a/szymborska-uratuje-polske [data dostępu: 15.02.2019].

https://poland.us/strona,55,21819,0,a-celebration-of-wislawa-szymborska-winner-of-the-nobel

-prize-in-new-york.html [data dostępu: 15.02.2019].

https://www.facebook.com/nobelprize/photos/ [data dostępu: 15.02.2019].

https://www.facebook.com/SztuczneFiolki/photos/a.483789074973669.115138.483774998308410/

486192604733316/?type=1\&theater [data dostępu: 15.02.2019].

https://www.vogue.pl/a/wislawa-szymborska-przyjmuje-nagrode-nobla [data dostępu: 15.02.2019]. Maliszewski K.: Szymborska w oczach następnych pokoleń. Ślady w wierszach i świadomości.

Wystąpienie Karola Maliszewskiego na konferencji naukowej Szymborska 20 lat po Noblu 1112 października 2016 r. http://www.szymborska.org.pl/dokumenty/1484817786_51805587_ Szymborska_w_oczach_nastepnych_pokolen.pdf [data dostępu: 15.02.2019].

Twardoch E.: „,Usieciowione” miejsca pamięci, czyli jak symbole przeszłości staja sie przestrzenia aktywności użytkowników sieci. http://www.ejournals.eu/sj/index.php/PK/article/view/4443/

4418 [data dostępu: 15.02.2019].

www.facebook.com/niebycbokserembycpoeta [data dostępu: 15.02.2019].

www.noblisci.pl/1996-wislawa-szymborska [data dostępu: 15.02.2019]. 